\title{
Neurogenic Locus Notch Homolog Protein 4
}

National Cancer Institute

\section{Source}

National Cancer Institute. Neurogenic Locus Notch Homolog Protein 4. NCI Thesaurus. Code C18054.

Neurogenic locus notch homolog protein 4 (2003 aa, $210 \mathrm{kDa}$ ) is encoded by the human NOT CH4 gene. This protein plays a role in both cell-fate determination and cellcell signaling. 